\title{
Use of Rice Husk Ash as Partial Replacement of Cement in Sandcrete Blocks
}

\author{
Wajid Khan', Muhammad Fahim ${ }^{1 *}$, Saeed Zaman', Sajjad Wali Khan', \\ Yasir Irfan Badrashi', Fayaz Khan' \\ 1 Department of Civil Engineering, University of Engineering and Technology, Peshawar, Pakistan \\ * Corresponding author's email:drmfahim@uetpeshawar.edu.pk
}

\begin{abstract}
This paper presents the outcome of a research study aimed at the performance evaluation of rice husk ash as partial replacement of cement in sandcrete blocks used as masonry units. Rice husk from the rice cultivated in the North of Pakistan was used in the study. It was first combusted in a locally manufactured incinerator to convert it into rice husk ash (RHA) and then finely ground to powder form for use with cement. Blocks with the size of $305 \times 203 \times 152$ $\mathrm{mm}$ were molded with $0,10,30,40$ and $50 \%$ replacement of cement with RHA to find compressive strength at $3,7,14$ and 28 days age of curing. The results showed that water requirement for the required workability of the sandcrete increased along with the RHA content, whereas the compressive strength decreased with increase in RHA content. However, the comparison of compressive strengths of RHA sandcrete blocks with the strength of commercial concrete blocks available in the market and used as masonry units in Pakistan showed that sandcrete blocks having the sand to binder ratio of $1: 8$ and using up to $40 \%$ of RHA as replacement of cement gave larger compressive strength than that of commercial concrete blocks and only marginally lower strength for $50 \%$ replacement.
\end{abstract}

Keywords: Rise husk ash, sandcrete blocks, compressive strength, masonry units, pozzolanic.

\section{INTRODUCTION}

The rising concern for environmental protection, energy source conservation and economy in the current times has created a pressing demand for the search of cement alternatives because of its very high carbon footprint, source depletion and high cost. Rice husk ash (RHA) is one of the materials that has been studied for their potential use as partial replacement of cement and have been placed by ASTM in the category of materials called pozzolans [1]. RHA is obtained by burning rice husk; the external hard covering of paddy rice grain received as waste material during rice milling process. The proportion of rice husk in paddy rice is $22 \%$ by weight that on burning loses $75 \%$ of the weight and the balance $22 \%$ is left as rice husk ash that was believed to have pozzolanic properties [2]. The global paddy rice production in year 2019 was 782 million tons [3] which implies
172 million tons of rice husk and 43 million tons RHA. These figures show that the use of RHA as partial replacement of cement can significantly contribute to environmental protection and fight against the climate change by reducing the cement demand and alleviation of the environmental hazards associated with dumping of waste RHA. Therefore, a good amount of research has been devoted to the use of RHA as cement replacement in concrete during the past decades.

Rahman [4] concluded that the water demand of mix increased along with RHA content and $40 \%$ of cement content can be replaced with RHA without significant change in 60 days compressive strength of sandcrete blocks. Okpala [5] found that the addition of RHA in cement paste increased both initial and final setting times, whereas the mix of 1:6 ratio with up to $40 \%$ cement replacement with RHA and the mix of $1: 8$ ratio with up to $30 \%$ replacement with 
RHA had adequate compressive strength for urban and rural dwellings in Nigeria. Cissea [6] used ground as well as unground RHA as partial replacement of cement in sandcrete blocks. The study revealed that the strength of the sandcrete with ground RHA was almost twice as high with unground RHA at all ages of curing; and the sandcrete utilizing both ground and unground sandcrete gave better strength as compared to sandcrete made with filled limestone or chert for same cement contents. Oeytola [7] studied the use of rice husk ash for the preparation of low cast sandcrete blocks in Nigeria. The strength of $150 \times 450 \mathrm{~mm}$ hollow concrete blocks was determined at 1, 3, 7, 14, 21 and 28 days for 10, 20, 30,40 and 50 percentage replacement of cement with RHA. The study concluded that the compressive strength increased with the age at curing and decreased with the percentage of RHA. The study recommended $20 \%$ as an optimum level of RHA usage as cement replacement. Agbede [8] studied the effect of partial substitution of Ordinary Portland Cement (OPC) with RHA on the compressive strength of hollow sandcrete block. The hollow blocks with the dimensions of $150 \times 22 \times 450 \mathrm{~mm}$ were crushed at 7,14 and 28 days of curing for $0,10,20,30,40,50$ and 60 percent replacement levels. The study recommended 17.5 per cent of cement replacement with RHA for sandcrete blocks used as building units. Aho [9] tested the hollow sandcrete blocks produced with $0,10,20,30,40$ and $50 \%$ of RHA replacement for cement at 1, 3, 7, 21 and 28 days of curing and recommended 30\% RHA for cement replacement for the production of hollow sandcrete blocks for use in Nigeria.

Olutoge [10] studied the effect of rice husk ash as a component of hollow sandcrete blocks. Two sizes $226 \times 225 \times 450 \mathrm{~mm}$ and $150 \times 225 \times 450$ $\mathrm{mm}$ were tested for various proportions of rice husks ash i.e. $0 \%, 4 \%, 10 \%, 20 \%$, and $30 \%$. The compressive strength of the samples were determined after 28 days. The study concluded that $10 \%$ ash replacement gave the strength required by the standard for building construction and it reduced the cost by $5.3 \%$. Oyekan and Kamiyo [11] investigated the physical and mechanical properties of concrete for 5 and $10 \%$ of RHA replacement. The study showed that water absorption increased along with the RHA content and the compressive strength of concrete decreased with the addition of RHA. It also showed that the difference of strength for $10 \%$ and $5 \%$ replacement with respect to the control mix was larger at 14 days than 28 days that proved that the gain of strength at old age decreased with increase in RHA content. The RHA content showed no relation to the splitting tensile strength and modulus of elasticity. Ettu [12] investigated the compressive strength of ternary blended cement sandcrete containing Afikpo RHA and sawdust ash (SDA) for $5 \%, 10 \%, 15 \%, 20 \%$, and $25 \%$ of cement replacement. The study suggested that very high sandcrete strength values could be obtained with OPC RHA-SDA ternary blended cement with richer mixes, high quality control, and longer days of hydration. Sangeetha [13] worked on replacement of OPC with $10 \%, 20 \%$, $30 \%$ \& $40 \%$ RHA in sandcrete blocks in India and investigated the compressive strength, setting time, consistency, workability and specific gravity of the blocks as well as performed a cost analysis. The study recommended $15-20 \%$ as optimum level of cement replacement with RHA in sandcrete blocks. Mayooran [14] studied the performance of high and low carbon content rice husk ash waste generated from open air burning of rice husk as partial replacement of cement in $215 \times 105 \times 65 \mathrm{~mm}$ sized blocks cast with the mix proportion of 1:5 cement and sand. The blocks prepared with $5 \%, 10 \%, 15 \%$ and $20 \%$ replacement levels were analyzed on the parameters of workability (water/binder ratio and setting time), strength (compressive, flexural bending and splitting tensile) and durability (water absorption, sorption, acid attack resistance and alkaline attack resistance). The study concluded that both types of RHA gave satisfactory results as per the standard for the maximum level of replacement used i.e., $20 \%$.

This paper presents the outcome of a study on the use of RHA produced in Pakistan as partial replacement of cement in sandcrete masonry blocks. Sandcrete is a building material made of Portland cement and sand in the ratio of 1:8. It is similar but weaker than mortar which normally has a ratio of 1:5. Since only moderate compressive strength is required for the sandcrete blocks used as masonry units; therefore, the block manufactured with higher proportion of RHA in place of cement are expected to possess sufficient compressive strength for practical use as masonry units and will open the way for commercial use of RHA as cement replacement in Pakistan and worldwide. This study is aimed at exploring this potential. 


\section{MATERIALS AND METHODS}

The research was organized on following lines to investigate the performance of RHA as partial replacement of cement in sandcrete blocks for use as masonry units:

- Rice Husk from the Swat variety of rice cultivated in Swat, Pakistan was used for the study.

- The husk was incinerated in a locally manufactured incinerator under controlled temperature and the ash was then allowed to cool at slow rate.

- The RHA was ground to the required fineness as per ASTM C618 requirement for use of pozzolanic material with cement and pozzolanic activity index was determined as per ASTM C311/C311M Standard.

- Sandcrete blocks with cement-sand ratio of 1:8 were cast and tested to find their compressive strength at 3, 7, 14 and 28 days age of curing for $0,10,20,30,40$ and $50 \%$ of cement replaced with RHA and the strengths were compared with that of commercial concrete blocks to analyze the performance of RHA as cement replacement and find optimum level of replacement.

\section{Incineration of Rise Husk}

The process of rice husk ash incineration is very important for its microstructure and later performance as pozzolanic or cementing agent. The reactivity of rice husk ash is greatly influenced by the temperature and duration of burning; and the cooling regime [15]. The incineration of rice husk for the study was carried out under controlled temperature conditions in the laboratory

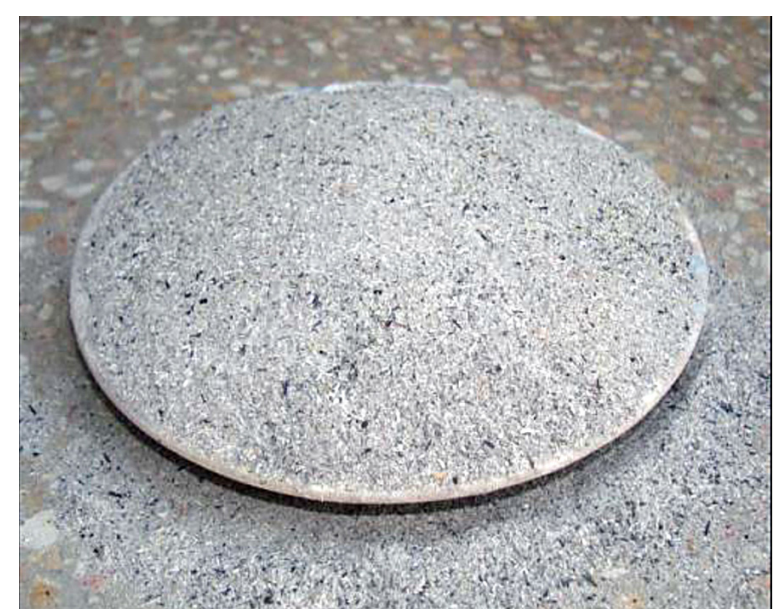

Fig. 1. Whitish grey rice husk ash produced by incineration
Table 1. Chemical composition of RHA by slow cooling

\begin{tabular}{|c|c|c|}
\hline S. No. & Component & Percentage \\
\hline 1 & $\mathrm{SiO}_{2}$ & 73 \\
\hline 2 & $\mathrm{Fe}_{2} \mathrm{O}_{3}$ & 3.1 \\
\hline 3 & $\mathrm{CaO}$ & 1.20 \\
\hline 4 & $\mathrm{Al}_{2} \mathrm{O}_{3}$ & 22.80 \\
\hline 5 & $\mathrm{NaO}$ & 0.16 \\
\hline 6 & $\mathrm{MgO}$ & 0.54 \\
\hline 7 & $\mathrm{~K}_{2} \mathrm{O}$ & 0.16 \\
\hline
\end{tabular}

with subsequent slow cooling during 10 hours after achieving the maximum temperature of 800 ${ }^{\circ} \mathrm{C}$. The white grey RHA achieved from the incineration process is shown in Figure 1.

\section{Chemical Compostion of RHA}

The chemical composition of RHA after going through the slow cooling is given in Table 1. $\mathrm{X}$-ray fluorescence analysis was used for determination of chemical composition. The silica content in the RHA was $73 \%$ that was in agreement with the previous published research and indicated high possible reactivity of RHA as pozzolanic/ cementing agent $[16,17]$.

\section{Grinding of RHA}

The RHA was ground to obtain the required fineness specified by ASTM 618-05 [18] for the use of pozzolanic materials with cement. The ground RHA gave only $15 \%$ retention on ASTM Sieve No. 325 when wet sieved against the minimum requirement of $34 \%$ retention.

\section{Conformity of RHA used in the Study to ASTM Standards}

Before ASTM C 618-05 [18] specifies minimum requirements for use of natural pozzolana as cementing agent in concrete, the standard specifies the minimum chemical composition requirement as well as physical properties for determining the conformability of a material for use as pozzolanic material in concrete.

The RHA used in the study satisfied the chemical composition criterion as the sum of silica $\left(\mathrm{SiO}_{2}\right)$, alumina $\left(\mathrm{Al}_{2} \mathrm{O}_{3}\right)$, and iron oxide $\left(\mathrm{Fe}_{2} \mathrm{O}_{3}\right)$ content was $98.90 \%$, significantly larger than the specified minimum of $70 \%$ as per ASTM C 618-05. 
Table 2. Physical requirements for pozzolanic material as per ASTM C 618-05

\begin{tabular}{|c|l|c|c|c|}
\hline S. No. & \multicolumn{1}{|c|}{ Property } & ASTM limit & Test value & Test (passed/failed) \\
\hline 1 & $\begin{array}{l}\text { Fineness: Amount retained when wet-sieved } \\
\text { on } 45 \mu \mathrm{m}(\text { No. 325) sieve (max \%) }\end{array}$ & 34 & 15 & passed \\
\hline 2 & $\begin{array}{l}\text { Strength activity index: } \\
\text { with Portland cement at } 7 \\
\text { days, min \% of control } \\
\text { with Portland cement at } 2 \\
\text { days, min \% of control }\end{array}$ & 75 & 93.67 & passed \\
\hline 3 & Water requirement, max \% of control & 75 & 80.09 & passed \\
\hline 4 & $\begin{array}{l}\text { Soundness: } \\
\text { autoclave expansion or contraction, max \% }\end{array}$ & 0.8 & 0.5 & passed \\
\hline
\end{tabular}

The physical conformability of RHA used in the study was also checked by performing the tests specified in the standard and comparing the results with the ASTM specifications. The physical conformability of the RHA as per ASTM C 618-05 is summarized in Table 2.

The description of materials used in the preparation of sandcrete blocks for the study is given hereunder:

\section{Cemenet}

Ordinary Portland cement conforming to ASTM C150-07 [19] standards from Cherat Cement Factory Nowshera, Pakistan was used in the preparation of blocks and cubes. The chemical composition of the cement is given in Table 3 .

\section{Fine Aggregate}

Locally available fine aggregate (sand) having fineness modulus 2.7 was used in the preparation of blocks and cubes. The sand was free of silt and organic material and was washed before use.

\section{Water}

Clean drinking water free of any physical impurity and chemical compounds, having near to room temperature was used for mix preparation.
Table 3. Chemical composition of cement

\begin{tabular}{|c|c|c|}
\hline S. No. & Constituent & Percentage \\
\hline 1 & $\mathrm{SiO}_{2}$ & 19.8 \\
\hline 2 & $\mathrm{CaO}$ & 62.45 \\
\hline 3 & $\mathrm{Al}_{2} \mathrm{O}_{3}$ & 6.9 \\
\hline 4 & $\mathrm{Fe}_{2} \mathrm{O}_{3}$ & 3.85 \\
\hline 5 & $\mathrm{SO}_{3}$ & 2.95 \\
\hline 6 & $\mathrm{MgO}$ & 2.35 \\
\hline
\end{tabular}

For control mix, the water binder ratio of 0.45 was used. The water binder ratio used for different RHA replacements are shown in the Table 4.

\section{Superplasticizers}

Superplasticizers were used in the range of $2-4 \%$ to gain adequate workability of the mix and waterbinder (cement + RHA) ratio. Superplasticizer was also used for higher degrees of RHA replacement i.e., for $30 \%$ and above to obtain a workable paste. The percentage of superplasticizer used for each level of RHA replacement is shown in the Table 4.

\section{Casting of Sandcrete Blocks}

The sandcrete blocks with the size of $305 \mathrm{~mm} \times 203 \mathrm{~mm} \times 152 \mathrm{~mm}$ were prepared as per standard ASTM C90 procedure [20]. The fine

Table 4. Water/binder ratio and quantity of superplasticizer

\begin{tabular}{|c|c|c|}
\hline $\begin{array}{c}\text { RHA replacement level } \\
\text { (\% of binder by weight) }\end{array}$ & Water/binder ratio & $\begin{array}{c}\text { Quantity of superplasticizer } \\
\text { (\% of binder weight) }\end{array}$ \\
\hline 0 & 0.45 & 0 \\
\hline 10 & 0.485 & 0 \\
\hline 20 & 0.5 & 0 \\
\hline 30 & 0.55 & 2 \\
\hline 40 & 0.55 & 3 \\
\hline 50 & 0.55 & 3 \\
\hline
\end{tabular}


Table 5. Compressive strength of sandcrete blocks

\begin{tabular}{|c|c|c|c|c|c|c|}
\hline \multirow{2}{*}{ Age of curing (days) } & \multicolumn{7}{|c|}{ Compressive strength (MPa) } \\
\cline { 2 - 7 } & Control mix & $10 \%$ RHA & $20 \%$ RHA & $30 \%$ RHA & $40 \%$ RHA & $50 \%$ RHA \\
\hline 3 & 2.73 & 2.75 & 2.17 & 2.10 & 1.58 & 0.81 \\
\hline 7 & 4.49 & 3.38 & 2.84 & 2.10 & 1.96 & 1.74 \\
\hline 14 & 5.76 & 5.64 & 4.53 & 3.00 & 2.91 & 1.96 \\
\hline 28 & 7.02 & 5.69 & 4.73 & 4.47 & 3.85 & 3.32 \\
\hline
\end{tabular}

aggregate (sand) having a fineness modulus of 2.7 was first washed with water to make it saturated and to make the silt and other impurities rise to the surface. The water along with silt and impurities was removed by tilting the pot, and the upper surface of the sand containing a thin layer of silt was scratched with spatula to make it free of all impurities. Sand was then spread in a large tray to bring it to the surface dry condition. Sand took 24 hours to become saturated and surface dry. Saturated and surface dry sand was then used for making sandcrete blocks. Each block was tamped in three layers; tamping each layer at least 25 times. The blocks were demolded after 24 hours and kept in water thereafter till the time of testing. The molding and storage of blocks was carried out at room temperature nearing $25^{\circ} \mathrm{C}$.

\section{Compressive Testing of Sandcrete Blocks}

The compression testing of the blocks was carried out in Material Testing Laboratory, University of Engineering \& Technology Peshawar, Pakistan. A $2000 \mathrm{kN}$ digital Universal Testing
Machine (UTM) was used for finding the compressive strength of blocks. The specimen were tested under slow rate of loading.

\section{RESULTS AND DISCUSSIONS}

The results of the compression testing of sandcrete blocks are summarized in Table 5, whereas the graph in Figure 2 shows gain of strength of blocks with age of curing for different replacement levels of cement with RHA. It is evident from Figure 2 that the compressive strength of sandcrete blocks decreases with the increase of the RHA content. The figure further shows that the gain of compressive strength with age of curing is almost linear for all replacement levels and gives same shape of graph as the control mix but of lower peaks. The difference of strength between the control and RHA sandcrete grows up with age of curing for all replacement levels suggestive of the higher pozzolanic activity of RHA during the early days of curing.

The variation of 28 days compressive strength of sandcrete blocks with the RHA

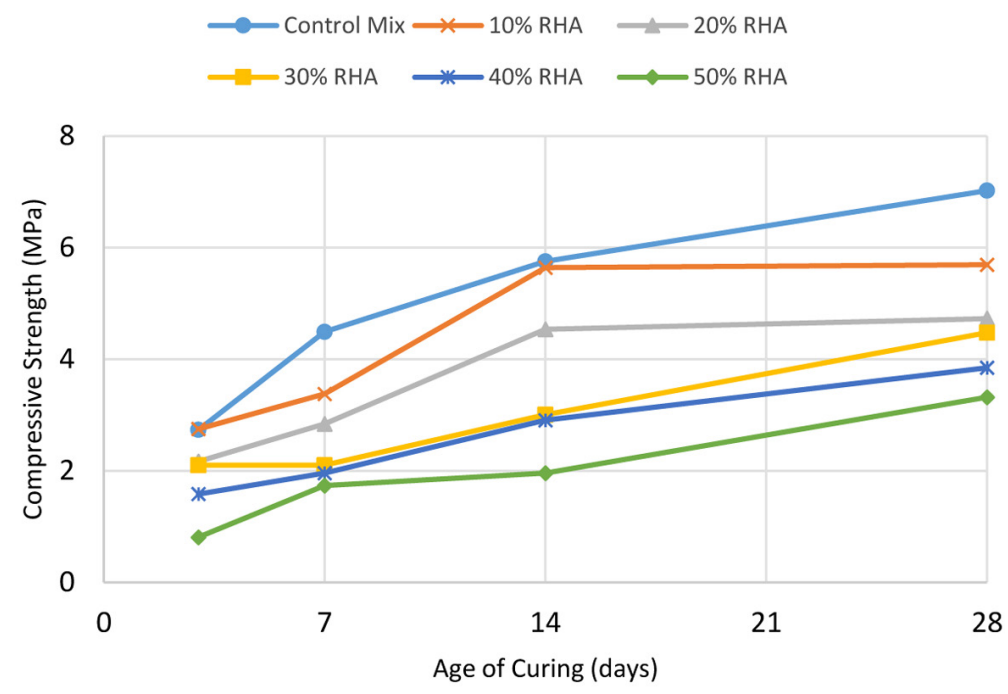

Fig. 2. Variation of compressive strength of blocks with age of curing 


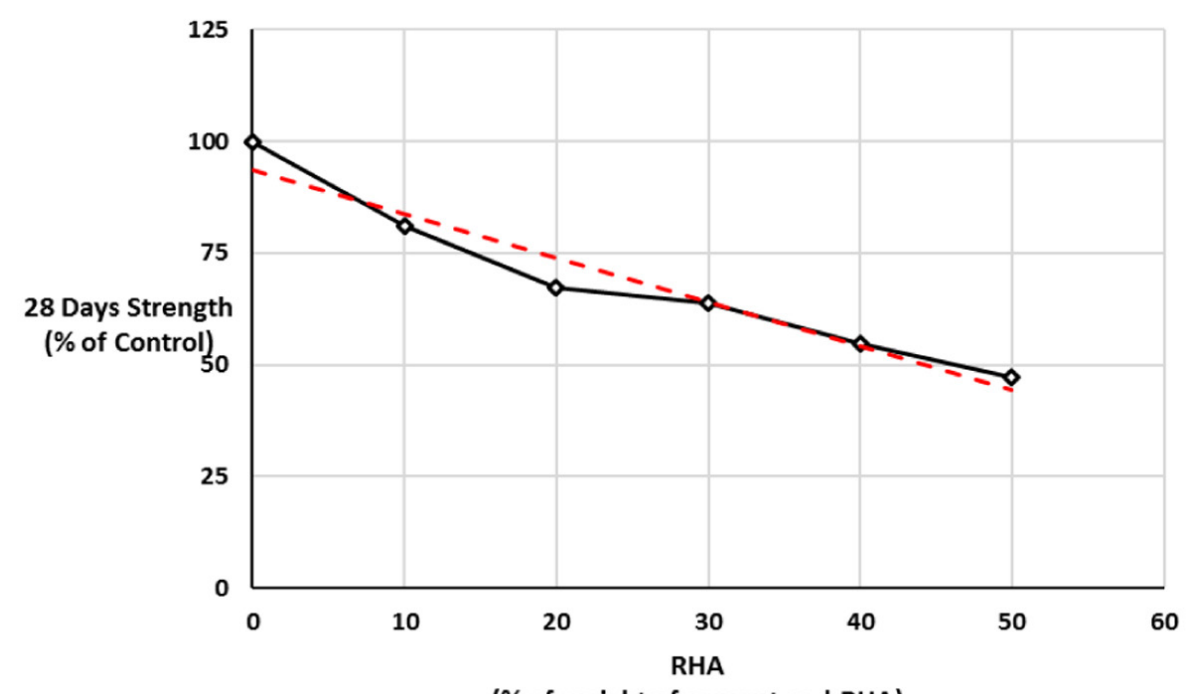

(\% of weight of cement and RHA)

Fig. 3. Percentage decrease in compressive strength with addition of RHA

content of the mix as shown in Figure 3 exhibits an almost linear decrease in strength with the increase of RHA content. The $50 \%$ replacement of cement with RHA reduces the 28 days compressive strength to half the 28 days strength of control mix.

The comparison of 28 days strength of sandcrete blocks with that of the commercially available concrete masonry blocks in the market is shown in Figure 4. The graph shows that the strength of the sandcrete blocks having $50 \%$ of RHA was slightly lower than that of the commercial concrete blocks, whereas all the other replacement levels gave the strength greater than that of the commercial concrete masonry blocks.

\section{CONCLUSIONS}

The RHA given by the incineration (under controlled conditions) of the husk obtained from the Swat variety of rice grown in the North of Pakistan met all the requirements of chemical composition as specified by ASTM C 618-05. The RHA obtained met all physical requirements of a material to be used as pozzolana as specified by ASTM C 618-05 including pozzolanic activity index which is the direct measure of the activity of RHA as cementing agent. The water requirements of the paste for a given slump increased along with the increase of the RHA content used as cement replacement. Addition of superplasticizer was needed for making the paste workable

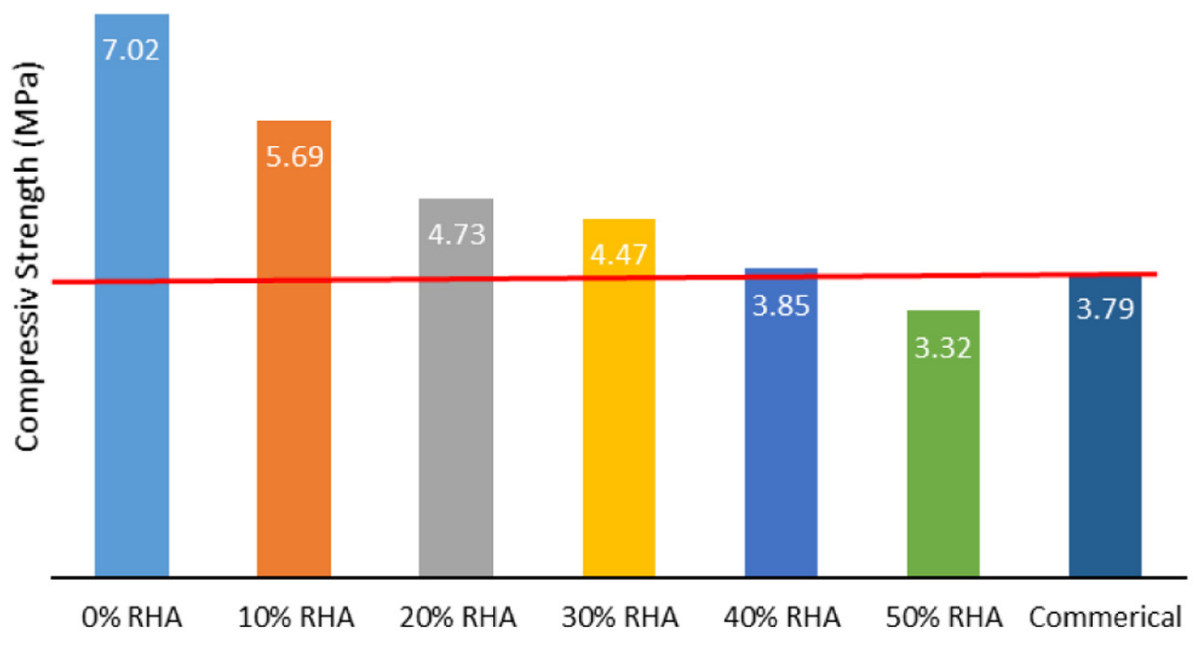

Fig. 4. Comparison of 28 days compressive strength 
for $30 \%$ and above level of the RHA content. The superplasticizer was used in 2 to $4 \%$ by weight of mix water. The compressive strength of RHA sandcrete at all ages of curing decreased with increase of the RHA proportion in the mix.

The comparison of compressive strengths of RHA sandcrete blocks with the strength of commercial concrete blocks available on the market and used as masonry units in Pakistan showed that sandcrete blocks having the sand to binder ratio of $1: 8$ and using up to $40 \%$ of RHA as replacement of cement gave larger compressive strength than that of commercial concrete blocks and only marginally lower strength for $50 \%$ replacement.

\section{Acknowledgment}

The authors are greatly thankful to the University of Engineering and Technology Peshawar, Pakistan and Pakistan Council of Scientific and Industrial Research (PCSIR) Laboratories Peshawar for providing the facilities of incineration, grinding, chemical analysis and compression testing for the study. Sincere thanks also go to Engr. Sajjad Ali for providing the rice husk from Swat, Pakistan for the research.

\section{REFERENCES}

1. Neville A.M., Properties of concrete. $5^{\text {th }}$ Edition, published by Pearson Education Limited, 2011, 83-84.

2. www. ricehuskash.com

3. Food and Agriculture Organization of the United Nations, http://www.fao.org/faostat/en/\#data/QC/ visualize

4. Rahman M.A., Use of rice husk ash in sandcrete blocks for masonry units, Materials and Structures, 20, 1987, 361-366.

5. Okpala D.C., Some engineering properties of sandcrete blocks containing rice husk ash. Building and Environment, 28(3), 1993, 235-241.

6. Cissea I.K., Laquerbea M., Mechanical characterisation of filler sandcretes with rice husk ash additions: Study applied to Senegal. Cement and Concrete Research, 30(1), 2000, 13-18.

7. Oyetola E.B.,Abdullahi M., The use of rice husk ash in low - cost sandcrete block production. Leonardo Electronic Journal of Practices and Technologies, 2006.
8. Agbede O. and Obam S.O., Compressive strength of rice husk ash-cement sandcrete blocks. Global Journal of Engineering Research, 7(1), 2008.

9. Aho M.I. and Utsev J.T., Compressive strength of hollow sandcrete blocks made with rice husk ash as a partial replacement to cement. Nigerian Journal of Technology, 27(2), 2008.

10. Olutoge F., Effect of rice husk ash in the production of hollow sandcrete block. Journal of Engineering and Technology, 5(1), 2009, 58-63.

11. Oyekan G.L. and Kamiyo O.M., A study on the engineering properties of sandcrete blocks produced with rice husk ash blended cement. Journal of Engineering and Technology Research, 3(3), 2011, 88-98.

12. Ettu O.L., Strength of ternary blended cement sandcrete containing afikpo rice husk ash and saw dust ash. American Journal of Engineering Research, 2(4), 2013, 133-137.

13. Sangeetha S.P., Rice husk ash sandcrete block as low cost building material. International Journal of Engineering Research and Application, 6(6), 2016, 46-49.

14. Mayooran S., Ragavan S., Sathiparan N., Comparative study on open air burnt low- and high-carbon rice husk ash as partial cement replacement in cement block production. Journal of Building Engineering, 13, 2017, 137-145.

15. Nair D.G., A structural investigation relating to the pozzolanic activity of rice husk ashes. Cement and Concrete Research, 38, 2008, 861-869.

16. Ali Memon S., Utilization of rice husk ash as viscosity modifying agent in self compacting concrete. Construction and Building Materials, 25(2), 2011, 1044-1048.

17. De Souza Rodrigues C., Rice husk ash as a supplementary raw material for the production of cellulose-cement composites with improved performance. Waste and Biomass Valorization, 1, 2010, 241-249.

18. ASTM C618-05, Standard Specification for Coal Fly Ash and Raw or Calcined Natural Pozzolan for Use in Concrete, ASTM International, West Conshohocken, PA, 2005.

19. ASTM C150-07, Standard Specification for Portland Cement; ASTM International, West Conshohocken, PA, 2007.

20. ASTM C90-16a, Standard Specification for Loadbearing Concrete Masonry Units, ASTM International, West Conshohocken, PA, 2016. 